\section{SOI: 1.1/TAS DOI: 10.15863/TAS International Scientific Journal Theoretical \& Applied Science}

p-ISSN: 2308-4944 (print) e-ISSN: 2409-0085 (online)

Year: $2018 \quad$ Issue: 09 Volume: 65

Published: 24.09.2018 http://T-Science.org
Muhammad Ayub

Dr., Assistant Professor

Gastroenterology DHQ Teaching Hospital Gujranwala Medical College Gujranwala mnaich@hotmail.com

Shehryar Noor Dr., consultant general surgeon in Khyber Teaching Hospital Peshawar, Pakistan. shehryar.md@gmail.com

SECTION 20. Medicine.
Kanwal Nasir

Dr., WMO in DHQ Nankana Sahib, Pakistan. kanwalllnasir43@gmail.com

\title{
ASSOCIATION OF H PYLORI INFECTION WITH IRON DEFFICIENCY ANEMIA AMONG OLDER PATIENTS
}

\begin{abstract}
Objective: Purpose of conducting this study was to determine association of hylori infection and anemia in old age patients.

Design \& Setting: This is a cross sectional study carried out in DHQ Teaching Hospital Gujranwala Medical College Gujranwala

Duration: Study was started in Febraury 2018 and completed in June 2018 comprising on 5 months duration.

Materials and Methods: All cases presenting with signs and symptoms of acid peptic disease in outpatientdoor were evaluated for H-Pylori infection. A performa was designed in which all related question were mentioned like age, signs and symptoms of H-pylori infection and peptic ulcer disease and clinical evident anemia important points of history, clinical examination and investigations were documented in it. An inclusion criteria was defined according to which only those cases were included in the study having $H$ pylori infection diagnosed on blood tests, urea breath test or stool culture and having no other chronic disease and having age above 30 years. All those cases with age below 30 years or having any other associated disease were not included in this study. Two blood samples of each patient were taken in two viles one sample for detecting H Pylori antibodies and second sample for determining serum ferritin level on ELISA. These samples were sent for tests to the laboratory of study institution. Obtained results were documented and analyzed on SPSS software version 2014.

Results: Out of 365 cases of acid peptic disease reported in OPD of study institution in duration of 5 months, only 86 cases were having $H$ pylori infection diagnosed by various tests and these cases were selected for study. These cases belonged to male and female both populations having age above 30 years. There were 46 male and 40 female cases in study group. Out of 86 cases 53 were diagnosed with peptic ulcer disease including 28 male and 25 female cases. Male patients were having age range of 35-75 years with mean age of 48.7 years and female patients with age range of 32-66 years with mean age of 41.3 years. Ferritin level between ranges of $15-19 \mathrm{ng} / \mathrm{ml}$ was present in 5 male cases and 10-14 $\mathrm{ng} / \mathrm{ml}$ in 9 male cases. While 6 male and 15 female cases were having ferritin level between $5-9 \mathrm{ng} / \mathrm{ml}$. One male case and 8 female cases were having ferritin level below $5 \mathrm{ng} / \mathrm{ml}$. Among 86 cases 44 cases had iron deficiency anemia and out of them 21 were male and 23 were female.

Conclusion: Helicobacter Pylori causes deficiency of iron in the body and leading to iron deficiency nemia. It is associated usually with infection of prolong duration.

Key words: Helicobacter infection, iron deficiency anemia, Anemia in older patients.

Language: English

Citation: Ayub M, Noor S, Nasir K (2018) ASSOCIATION OF H PYLORI INFECTION WITH IRON DEFFICIENCY ANEMIA AMONG OLDER PATIENTS. ISJ Theoretical \& Applied Science, 09 (65): 101-105.

Soi: http://s-o-i.org/1.1/TAS-09-65-15 Doi: crossef https://dx.doi.org/10.15863/TAS.2018.09.65.15
\end{abstract}

\section{INTRODUCTION}

Helicobacter pylori is also known as Campylobacter pylori is a gram negative microaerophilic bacterium living in gastrointestinal system and mostly infects stomach and duodenum. It is transmitted via feco oral route. ${ }^{1}$ People having this infection usually present with upper abdominal pain, chest burn, indigestion, nausea, loss of appetite, bloating and weight loss. Many people are not symptomatic while having this infection and present late to doctor when signs and symptoms start appearing. ${ }^{2}$ This infection can be diagnosed by various tests such as urea breath test, stool culture, ELISA for $h$ pylori and endoscopic biopsy for 
histopathology. Urea breath test is a very accurate method of diagnosing infection. $\mathrm{H}$ pylori causes gastritis and patient complains of pain in stomach after taking meal. This infection can be treated by conservative management using antibiotics and antacids. ${ }^{3}$ Usually triple regimen of clarithromycin $500 \mathrm{mg}$ bid, amoxicillin $1 \mathrm{~g}$ bid and omeprazole bid. There are other regimens as well. This treatment is very effective in eradicating infection. $\mathrm{H}$ pylori causes iron deficiency in the patients leading to anemia. Such cases are pale and lethargic. Their iron store of body are depleted which can be measured by serum feritin level. ${ }^{4}$ In this study patients with $\mathrm{h}$ pylori infection were evaluated for iron deficiency anemia. In this study both male and female cases were included having age above 30 years. It was seen that anemia was most likely to occur in prolonged infection and almost equally involving both male and female patients. ${ }^{5,6}$ Unhygienic eating habbits and life style increases risk of its infection. Many studies have shown that this infection is more common in underdeveloped and developing countries while in well developed countries its prevalence is low. When $\mathrm{h}$ pylori infection occurs in a pregnant woman it may cause severe anemia as shown by a study of Weyermann conducted on pregnant ladies with $h$ pylori infection reported low hemoglobin level at the start of gestational period which became severe further latter on. Due to iron deficiency anemia performance of patient is disturbed. ${ }^{7,8}$ It causes immunodeficiency and also makes pregnancy difficult to be completed successfully. This infection causes ulcer of stomach usually in lesser curvature and duodenal ulcer in first or second part of duodenum mostly. People with peptic ulcer are usually obese. In iron deficiency anemia oral or inravenous iron replacement was successful and increases hemoglobin level and reducing anemic symptoms but when treatment is stopped anemia occurs again so definitive treatment is to eradicate $h$ pylori infection in the patient.

\section{Materials and Methods}

This is a cross sectional study conducted in a teaching hospital. This study was completed in duration of five months. All cases presenting with signs and symptoms of acid peptic disease in outpatient-door were evaluated for H-Pylori infection. Blood samples for test were drawn from venous blood and stored in a glass vile. Serum was obtained from the sample and tests were performed. A performa was designed in which all related question were mentioned like age, signs and symptoms of H-pylori infection and peptic ulcer disease and clinical evident anemia important points of history, clinical examination and investigations were documented in it. An inclusion criteria was defined according to which only those cases were included in the study having $\mathrm{H}$ pylori infection diagnosed on blood tests, urea breath test or stool culture and having no other chronic disease and having age above 30 years. All those cases with age below 30 years or having any other associated disease were not included in this study. . People having this infection usually present with upper abdominal pain, chest burn, indigestion, nausea, loss of appetite, bloating and weight loss. Many people are not symptomatic while having this infection and present late to doctor when signs and symptoms start appearing. This infection can be diagnosed by various tests such as urea breath test, stool culture, ELISA for $\mathrm{h}$ pylori and endoscopic biopsy for histopathology.Two blood samples of each patient were taken in two viles one sample for detecting $\mathrm{H}$ Pylori antibodies and second sample for determining serum ferritin level on ELISA. These samples were sent for tests to the laboratory of study institution. Obtained results were documented and analyzed on SPSS software version 2014. Ferritin level was detected in blood by ELISA which is an investigation of choice for it. Normal range of ferritin level in the body is $10-120 \mathrm{ng} / \mathrm{ml}$ and $20-250 \mathrm{ng} / \mathrm{ml}$ in males and females respectively according to BioCheck scale.

\section{Results}

Study subjects were selected in outpatient door of study hospital. Out of 365 cases of acid peptic disease reported in OPD of study institution in duration of 5 months, only 86 cases were having $\mathrm{H}$ pylori infection diagnosed on various tests and these cases were selected for study. These cases belonged to male and female both populations having age above 30 years. There were $46(53.5 \%)$ male and $40(46.5 \%)$ female cases in study group. Out of 86 cases $53(61.6 \%)$ were diagnosed with peptic ulcer disease including 28(52.8\%) male and 25(47.2\%) female cases. Male patients were having age range of 35-75 years with mean age+-SD of 48.7+-12.8 years and female patients with age range of 32-66 years with mean age +-SD of $41.3+-13.6$ years. Out of total 21 males and 23 females with anemia, ferritin level between ranges of $15-19 \mathrm{ng} / \mathrm{ml}$ was present in $5(23.8 \%)$ males and $10-14 \mathrm{ng} / \mathrm{ml}$ in $9(42.8 \%)$ male cases. While $6(28.6 \%)$ male and $15(65.2 \%)$ female cases were having ferritin level between $5-9 \mathrm{ng} / \mathrm{ml}$, one $(4.7 \%)$ male case and $8(34.9)$ female cases were having ferritin level below $5 \mathrm{ng} / \mathrm{ml}$. Among 86 cases $44(51.2 \%)$ cases had iron deficiency anemia and out of them $21(47.7 \%)$ were male and $23(52.3 \%$ ) were female pattients. 


\begin{tabular}{l|lr|ll|ll} 
& ISRA (India) & $=\mathbf{1 . 3 4 4}$ & SIS (USA) & $=\mathbf{0 . 9 1 2}$ & ICV (Poland) & $=\mathbf{6 . 6 3 0}$ \\
Impact Factor: & ISI (Dubai, UAE) $=\mathbf{0 . 8 2 9}$ & PUHЦ (Russia) $=\mathbf{0 . 1 5 6}$ & PIF (India) & $=\mathbf{1 . 9 4 0}$ \\
& GIF (Australia) & $=\mathbf{0 . 5 6 4}$ & ESJI (KZ) & $=\mathbf{4 . 1 0 2}$ & IBI (India) & $=\mathbf{4 . 2 6 0}$ \\
& JIF & $\mathbf{1 . 5 0 0}$ & SJIF (Morocco) & $\mathbf{2 . 0 3 1}$ & & \\
\hline
\end{tabular}

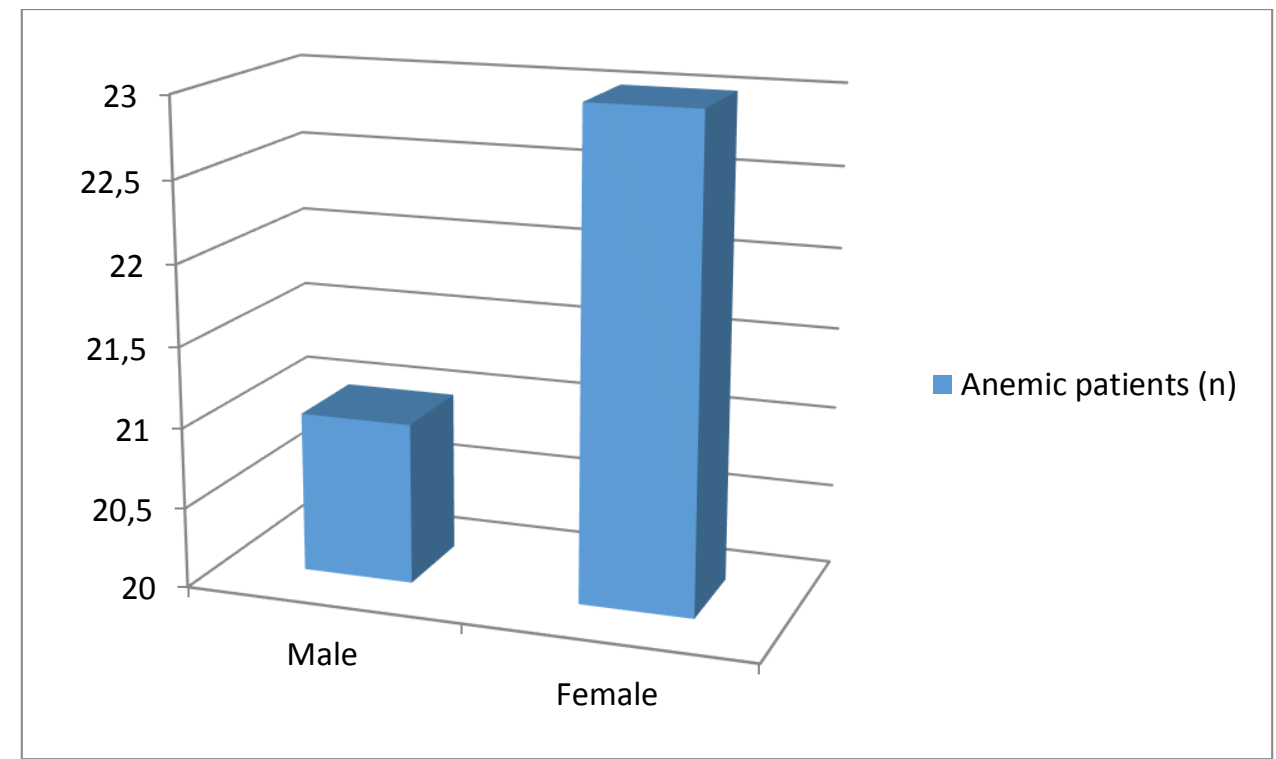

Figure-1 Gender distribution of anemic patients out of total 44 anemic cases

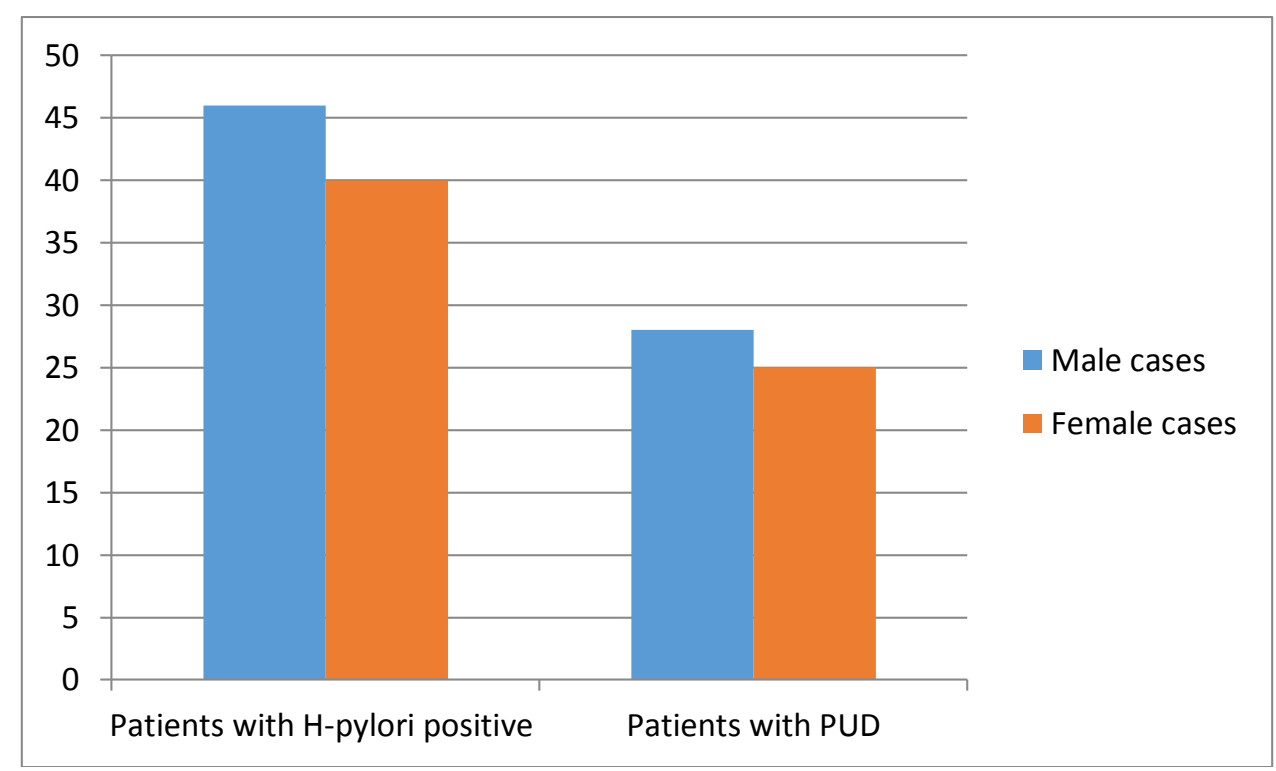

Figure-2 Frequency of Patients with H-pylori infection having Peptic ulcer disease

Table-1

Age distribution among patients of study group

\begin{tabular}{|c|c|c|c|c|}
\hline \multirow{2}{*}{$\begin{array}{c}\text { Age of patients } \\
\text { (years) }\end{array}$} & \multicolumn{2}{|c|}{ Male Patients $(n=46)$} & \multicolumn{2}{|c|}{ Female Patients $\quad(n=40)$} \\
\hline & $\mathbf{N}$ & $\%$ & $\mathbf{N}$ & $\%$ \\
\hline $20-30$ & 4 & 8.7 & 5 & 12.5 \\
\hline $31-40$ & 7 & 15.2 & 6 & 15 \\
\hline $41-50$ & 11 & 23.9 & 12 & 30 \\
\hline $51-60$ & 13 & 28.3 & 9 & 22.5 \\
\hline $61-70$ & 6 & 13 & 4 & 10 \\
\hline Above 70 & 5 & 10.9 & 3 & 7.5 \\
\hline
\end{tabular}


Frequency of patients with low serum ferritin level

\begin{tabular}{|c|c|c|c|c|c|}
\hline \multirow[t]{2}{*}{$\begin{array}{l}\text { Serum ferritin } \\
\text { level (ng/ml) }\end{array}$} & \multicolumn{2}{|c|}{$\begin{array}{c}\text { Male patients }(\mathrm{n}=46) \\
\text { Normal range }(20-250 \mathrm{ng} / \mathrm{ml})\end{array}$} & \multicolumn{2}{|c|}{$\begin{array}{c}\text { Female patients }(\mathrm{n}=40) \\
\text { Normal range }(10-120 \mathrm{ng} / \mathrm{ml})\end{array}$} & P Value \\
\hline & $\mathrm{N}$ & $\%$ & $\mathrm{~N}$ & $\%$ & \multirow{6}{*}{0.04} \\
\hline 15-19 & 5 & 10.8 & - & & \\
\hline $10-14$ & 9 & 19.5 & - & & \\
\hline $5-9$ & 6 & 13.04 & 15 & 37.5 & \\
\hline Below 5 & 1 & 2.2 & 8 & 20 & \\
\hline Total & 21 & & 23 & & \\
\hline
\end{tabular}

\section{DISCUSSION}

Helicobacter pylori infection is very common among people worldwide. ${ }^{9}$ This infection involves stomach and small intestine. This causes gastritis and if untreated may lead to peptic ulcer disease, perforation of duodenum and gastric lymphoma etc. ${ }^{10-13}$ In this study all patients were vitally stable without lethal complications of H-pylori like perforation and lymphoma. In this study association of h-pylori infection and iron deficiency anemia was determined. Helicobacter pylori is also known as Campylobacter pylori is a gram negative microaerophilic bacterium living in gastrointestinal system and mostly infects stomach and duodenum. It is transmitted via feco oral route. People having this infection usually present with upper abdominal pain, chest burn, indigestion, nausea, loss of appetite, bloating and weight loss. ${ }^{14}$ Many people are not symptomatic while having this infection and present late to doctor when signs and symptoms start appearing. This infection can be diagnosed by various tests such as urea breath test, stool culture, ELISA for $h$ pylori and endoscopic biopsy for histopathology. Urea breath test is a very accurate method of diagnosing infection. This is a cross sectional study conducted in a teaching hospital. This study was completed in duration of five months. ${ }^{15}$ All cases presenting with signs and symptoms of acid peptic disease in outpatient-door were evaluated for H-Pylori infection. Blood samples for test were drawn from venous blood and stored in a glass vile. Serum was obtained from the sample and tests were performed. A performa was designed in which all related question were mentioned like age, signs and symptoms of H-pylori infection and peptic ulcer disease and clinical evident anemia important points of history, clinical examination and investigations were documented in it. Study subjects were selected in outpatient door of study hospital. ${ }^{16}$ Out of 365 cases of acid peptic disease reported in OPD of study institution in duration of 5 months, only 86 cases were having $\mathrm{H}$ pylori infection diagnosed on various tests and these cases were selected for study. These cases belonged to male and female both populations having age above 30 years. There were 46(53.5\%) male and $40(46.5 \%)$ female cases in study group. Out of 86 cases $53(61.6 \%)$ were diagnosed with peptic ulcer disease including $28(52.8 \%)$ male and $25(47.2 \%)$ female cases. Usually triple regimen of clarithromycin $500 \mathrm{mg}$ bid, amoxicillin $1 \mathrm{~g}$ bid and omeprazole bid. There are other regimens as well. This treatment is very effective in eradicating infection. $\mathrm{H}$ pylori causes iron deficiency in the patients leading to anemia. Such cases are pale and lethargic. ${ }^{17}$ Their iron store of body are depleted which can be measured by serum feritin level. In this study patients with h pylori infection were evaluated for iron deficiency anemia. In this study both male and female cases were included having age above 30 years. It was seen that anemia was most likely to occur in prolonged infection and almost equally involving both male and female patients. ${ }^{18}$ A study done in Alaska concluded high prevalence of $\mathrm{H}$ pylori infection causing iron deficiency anemia in most of the people with infection. Another study done by Boggs reported increasw in serum ferritin level after taking triple regimen for $\mathrm{H}$-pylori eradication in study cases.

\section{CONCLUSION}

H-pylori infection has high prevalence and involves gastrointestinal tract causing many complications mainly peptic ulcer disease. It is associated with iron deficiency anemia. If treated properly, anemia can be corrected. Triple regimen for $\mathrm{H}$-pylori eradication is effective in reducing anemia. Initially anemia should be corrected with oral or intravenous iron therapy. Unhygienic life style is main cause of this infection. 


\begin{tabular}{l|lr|ll|ll} 
& ISRA (India) & $=\mathbf{1 . 3 4 4}$ & SIS (USA) & $=\mathbf{0 . 9 1 2}$ & ICV (Poland) & $=\mathbf{6 . 6 3 0}$ \\
Impact Factor: & ISI (Dubai, UAE) $=\mathbf{0 . 8 2 9}$ & PUHЦ (Russia) $=\mathbf{0 . 1 5 6}$ & PIF (India) & $=\mathbf{1 . 9 4 0}$ \\
& GIF (Australia) & $=\mathbf{0 . 5 6 4}$ & ESJI (KZ) & $=\mathbf{4 . 1 0 2}$ & IBI (India) & $=\mathbf{4 . 2 6 0}$ \\
& JIF & $=\mathbf{1 . 5 0 0}$ & SJIF (Morocco) $=\mathbf{2 . 0 3 1}$ & & \\
\hline
\end{tabular}

\section{References:}

1. Cardenas VM, Mulla ZD, Ortiz M, Graham DY. (2006) Iron deficiency and Helicobacter pylori infection in the United States. Am J Epidemiol 2006; 163: 127-34.

2. Sungthong R, Mo-Suwan L, Chongsuvivatwong V. (2002) Effect of haemoglobin and serum ferritin on cognitive function in school children. Asia Pac J Clin Nutr 2002; 11: 117-22.

3. DuBois S, Kearney DJ. (2005) Iron deficiency anaemia and Helicobacter pylori infection. review of the evidence. A J Gastroentrol 2005;100: 453-9.

4. Milman N, Rosenstock S, Andersen L, Jorgensen T, Bonnevie O. (1998) Serum ferritin, hemoglobin and helicobacter pylori infection: a seroepidemiologic survey comprising 2794 Danish adults. Gastroenterology 1998; 115: 268-74.

5. Seo JK, Ko JS, Choi KD. (2002) Serum ferritin and helicobacter pylori infection in children: a sero- epidemiologic study in Korea. J Gastroenterol Hepatol 2002; 17: 754-7.

6. Hacihanefioglu A, Edebali F, Celebi A, Karakaya T, Senturk 0, Hulagu S. (2004) Improvement of complete blood count in patients with iron deficiency anaemia and Helicobacter pylori infection after the eradication of Helicobacter pylori. Hepatogastroenterology 2004; 51: 313-5.

7. Valiyaveettil AN, Hamide A, Bobby Z, Krishnan R. (2005) Effect of anti-helicobacter pylori therapy on outcome of iron-deficiency anaemia: a randomized, controlled study. Indian J Gastroenterol 2005; 24: 155-7.

8. Choi J W, (2003) Dose Helicobacter pylori infection relate to iron deficiency anaemia in prepubescent children under 12 years of age? Acta Pediatr 2003; 92: 970-2.

9. Baggett H C. Parkinson A J, Muth PT, Muth PT, Gold BD, Gessner BD, et al. (2006) Endemic iron deficiency associated with Helicobacter pylori infection among school- aged children in Alaska. Pediatrics 2006; 117 : e396-404

10. Suoglu OD, Gokce S, Saglam AT, Sokucu S, Saner G. (2007) Association of Helicobacter pylori infection with gastroduodenal disease, epidemiologic factors and iron- deficiency anaemia in Turkish children undergoing ednoscopy and impact on growth. Pediatr Int 2007; 49: 858-63.

11. Aziz S, Muzaffar R, Hafiz S, Abbas Z, Zafar MN, Naqvi SA, Rizvi SA. (2007) Helicobacter Pilori,Hepatitis viruses A, C, E, Antibodies \& $\mathrm{HBsAg}$ - prevalence \& associated risk factors in pediatric communities of Karachi. J Coli Physicians Surg Pak 2007; 17: 195-8.

12. Czihn SJ (2005) Helicobacter Pylori infection:Vr:detection, investigation, and management. J pediatr. 2005; 146: 521-6.

13. Hveem K, Kriiger Q. (2003) Epidemiology \& transmission. Helicobacter 2003; 8: 385-97.

14. Conrad ME, Umberti J N, (2000) Iron absorption and transport and update. Am J Hematol 2000; 64: 287-98.

15. Jais M, Barua S. (2004) Seroprevalence of anti Helicobacter pylori IgG/ IgA in asymptomatic population from Delhi. J Commum Dis 2004; 36: $132-5$.

16. Winocur D, Ceriani Cernadas 1M, lmach E, Otasso JC, Morales P, Gards A. (2004) [Prevalence of iron deficiency anaemia in a group of pre-school and school children, living in conditions of poverty]. Medicina (B Aires) 2004; 64: 481-6.

17. Berg G, Bode G, Blettner $\mathrm{M}$, Boeing $\mathrm{H}$, Brenner H. (2001) Helicobacter pylori infection and serum ferritin: A population-based study among 1806 adults in Germany. Am J Gastroenterol 2001; 96: 1014-8.

18. Gasbarrini A, Carloni E, Gasbarrini G, Chisholm SA. (2004) Helicobacter pylori and extragastric diseases other helicobacter. Helicobacter 2004; 9 (Supp 1): 57-66. 